\title{
Pemberian Patulin Menyebabkan Kerusakan Struktur dan Ultra Struktur Hepatosit Mencit
}

\section{Patulin Administration Causing the Damage on Mice's Hepatocyte Structure and Ultra Structure}

\author{
Utami Sri Hastuti \\ Laboratorium Mikrobiologi Fakultas Biologi-FMIPA Universitas Negeri Malang
}

\begin{abstract}
ABSTRAK
Patulin ialah sejenis mikotoksin yang terutama dihasilkan oleh kapang Aspergillus clavatus dan dapat mengkontaminasi beberapa macam biji-bijian, seperti: kacang tanah, kedelai, merica, terutama biji-biji yang telah mengalami kerusakan dan bersifat nephrotoksik maupun hepatotoksik. Penelitian eksperimental ini dilakukan dengan tujuan untuk mengetahui pengaruh patulin dalam berbagai dosis terhadap kerusakan struktural dan ultra struktural hepatosit mencit dengan menggunakan 24 ekor mencit (Mus musculus) jantan var. BALB-C umur 3 bulan. Mencit kelompok eksperimen diberi patulin per oral dengan 3 macam dosis, terdiri dari dosis 1, yaitu: $1 \mathrm{mg} / \mathrm{kg} \mathrm{BB}$; dosis 2, yaitu: 1,75mg/kg BB; dosis 3, yaitu: $2,5 \mathrm{mg} / \mathrm{kg}$ BB. Kerusakan struktur hepatosit diperiksa pada zona-zona centrilobular, midzonal, dan perifer. Kerusakan struktur hepatosit diperiksa secara histopatologi dan kerusakan ultra struktur diperiksa dengan Transmission Electron Microscope (TEM). Hasil penelitian menunjukkan bahwa: 1) patulin dapat menyebabkan kerusakan struktur maupun ultra struktur hepatosit mencit; 2) ada pengaruh perbedaan dosis patulin terhadap tingkat kerusakan struktur hepatosit mencit; makin tinggi dosis patulin, makin tinggi tingkat kerusakan yang diakibatkannya; 3 ) dosis patulin ke III (2,5mg/kg BB) merupakan dosis tertinggi yang menyebabkan kerusakan struktur hepatosit mencit; 4) ada perbedaan pengaruh patulin terhadap kerusakan struktur hepatosit pada ketiga zona lobulus hepar mencit; 5) zona lubulus hepar mencit yang mengalami kerusakan struktur hepatosit tertinggi ialah zona perifer.
\end{abstract}

Kata Kunci: Dosis patulin, kerusakan struktur hepatosit, kerusakan ultra struktur hepatosit, zona-zona lobulus hepar

\section{ABSTRACT}

Patulin is a mycotoxin specially produced by Aspergillus clavatus and can contaminate several beans, like peanuts, soy beans and papper, especially the damage one with nephrotoxic as well as hepatoxic effects. This experimental study was conducted in order to know the effect of patulin in different doses towards the mice hepatocyte structural and untrastructural damage by using male and tree months age of BALB-C mice (Mus musculus). They were devided into 4 groups which were orally administered with patulin in three different doses. Those were $1 \mathrm{mg} / \mathrm{kg} \mathrm{BW,} \mathrm{1,75mg/kg} \mathrm{BW,} \mathrm{and}$ $2,5 \mathrm{mg} / \mathrm{kg}$ BW respectively. Structural damage of hepatocytes on centrilobular, midzonal, and peripheral zones ware observed and examined histopathologically and the ultra structural damage ware examined using Transmission Electron Microscope (TEM). Results of this study showed that: 1) there was an effect of patulin to mice hepatocyte structure damaged as well as ultra structure damaged; 2) there was a difference effect of some dose of patulin on the value of mice hepatocyte structure damage. The level of mice hepatocyte structure damage was riced as well as the increase of patulin doses; 3) dose-3 $(2,5 \mathrm{mg} / \mathrm{kg} \mathrm{BW})$ is the highest dose which cause the highest structural mice hepatocyte damage; 4) there was different effect of patulin to mice hepatocyte structure damage on the three zones of hepar lobulus; 5) the perifer zone was the highest damaged area of the three hepar lobulus zones.

Keywords: Hepatocyte structure damage, hepatocyte ultra structure damage, patulin dose

Jurnal Kedokteran Brawijaya, Vol. 28, No. 2, Agustus 2014; Korespondensi: Utami Sri Hastuti. Laboratorium Mikrobiologi Fakultas Biologi-FMIPA Universitas Negeri Malang, Jl.Semarang 5 Malang 651145 Tel. (0341)562180Email: tuti_bio_um@yahoo.com 


\section{PENDAHULUAN}

Patulin merupakan salah satu jenis mikotoksin yang dihasilkan oleh kapang Aspergillus clavatus, Penicillium patulum, dan Penicillium claviforme. Spesies-spesies kapang tersebut dapat mengkontaminasi berbagai macam bahan makanan, terutama biji-bijian yang telah mengalami kerusakan dengan ciri-ciri antara lain: biji berlubang, berkeriput, mengelupas; sehingga lebih mudah terkontaminasi oleh spora-spora kapang, bila dibandingkan dengan biji-biji utuh (1). Kapang Aspergillus clavatus dapat mengkontaminasi jagung dan gandum (2). Spesies kapang ini juga dapat mengkontaminasi biji kacang tanah dan biji kenari (3).

Mikotoksin merupakan toksin yang dihasilkan oleh beberapa spesies kapang dan bertanggung jawab untuk berbagai kasus keracunan pangan (4). Mikotoksin dihasilkan oleh kapang sebagai salah satu macam metabolit sekunder dalam proses metabolismenya dapat bersifat hepatotoksik, nephrotoksik, neurotoksik, teratogenik, dan karsinogenik (5). Kapang kontaminan pada bahan makanan, misalnya: biji-bijian menghasilkan spora-spora yang akan berkecambah membentuk hifa. Bila kondisi lingkungan optimum, hifa akan membentuk miselium yang tumbuh menembus substrat (6), selanjutnya kapang dapat menghasilkan metabolit primer dan metabolit sekunder yang mengkontaminasi bahan makanan.

Patulin dikenal sebagai mikotoksin yang bersifat nephrotoksik, neurotoksik, dan hepatotoksik. Hal ini diperkuat dengan ditemukannya perubahan-perubahan patologik yang terjadi pada tikus yang diperlakukan dengan patulin per oral berupa oedema dengan pendarahan, kerusakan pembuluh kapiler dalam ginjal dan limpa, serta oedema dalam otak (7). Walau disebutkan bahwa patulin juga bersifat hepatotoksik (5, 8), namun informasi tentang pengaruh patulin terhadap kerusakan struktur hepatosit pada zona-zona lobulus hepar masih belum ada.

Patulin yang terpapar ke dalam tubuh bersama-sama makanan yang dikonsumsi akan tersebar melalui sistem peredaran darah dan akan berpengaruh pada organ-organ yang dilalui oleh pembuluh darah. Berdasarkan hal tersebut, ada kemungkinan bahwa patulin selain dapat menyebabkan kerusakan struktur sel-sel ginjal, juga dapat menyebabkan kerusakan struktur hepatosit. Kerusakan struktur hepatosit dapat terjadi pada hepatosit-hepatosit yang terdapat pada ketiga zona lobulus hepar, yaitu : zona perifer, zona midzonal, dan zona centrilobular. Sampai saat ini belum ada informasi mengenai pengaruh patulin terhadap kerusakan struktur hepatosit pada tahap-tahap degenerasi keruh, degenerasi hidropik, degenerasi lemak, dan nekrosis. Hepatosit dapat mengalami kerusakan struktur maupun ultra struktur, yaitu pada tingkat organela sel akibat paparan mikotoksin $(5,7)$

Hepar merupakan organ utama yang berperan penting dalam proses metabolisme berbagai macam senyawa, termasuk mikotoksin yang terpapar ke dalam tubuh. Di dalam hepar terjadi biotransformasi terhadap mikotoksin-mikotoksin yang masuk ke dalam tubuh bersama makanan (7). Dalam proses biotransformasi tersebut, mikotoksin dapat mengalami bioaktivasi menjadi senyawa lain yang bersifat lebih toksik bila dibandingkan dengan senyawa asli. Hal ini mengakibatkan fungsi detoksifikasi menurun, sehingga mikotoksin tersebut berikatan dengan mikromolekul-mikromolekul lain dalam sel. Sel-sel yang menyusun jaringan hepar dapat mengalami jejas seluler. Salah satu faktor penyebab jejas seluler ialah toksin yang dihasilkan oleh mikroorganisme (9). Penelitian ini bertujuan untuk mengetahui pengaruh pemberian patulin terhadap kerusakan struktur dan ultra struktur hepatosit mencit pada tiga zone lobulus hepar yaitu zona perifer, midzonal, dan zona centrilobular.

\section{METODA}

Penelitian eksperimental dilakukan dengan rancangan acak kelompok di laboratorium Farmasi UNAIR, laboratorium Patologi FK UNAIR, dan laboratorium Mikroskopi Elektron UNAIR. Penelitian ini menggunakan hewan coba berupa mencit (Mus musculus) galur BALB-C jantan berumur 3 bulan dengan berat badan antara 25-30 gram, yang berasal dari PUS FETMA Wonocolo, Surabaya. 24 ekor sampel mencit tersebut dibagi menjadi 4 kelompok, dimasukkan dalam 4 kandang yang terpisah, masing-masing berisi 6 ekor mencit, yaitu: 3 kandang sebagai kelompok eksperimen, dan 1 kandang sebagai kelopok kontrol. Setelah melalui masa adaptasi selama 10 hari, semua mencit dari 3 kelompok eksperimen masingmasing dipapar dengan patulin. Kelompok I dengan dosis $1 \mathrm{mg} / \mathrm{kg} \mathrm{BB}$, kelompok II dengan dosis $1,75 \mathrm{mg} / \mathrm{kg} \mathrm{BB}$, dan kelompok III dengan dosis 2,5mg/kg BB. Pemaparan dilakukan setiap hari selama 4 hari, sedangkan kelompok kontrol hanya diberi solutio petit yang merupakan bahan pelarut dari patulin. Pemaparan masing-masing larutan patulin dan solutio petit dilakukan dengan menggunakan sonde yang dimasukkan ke dalam mulut mencit.

Setelah 4 hari mencit dimatikan secara etik yaitu dengan cara diambil darahnya secara intrakardial, kemudian dinding perut dibuka dan heparnya diambil. Lalu hepar dipotong untuk dibuat sediaan histopatologik. Potongan hepar diproses sesuai standar lalu dibuat blok dalam parafin dan diiris setebal 3 mikron untuk dibuat sediaan. Sediaan dicat dengan pewarna haematoxylin eosin (HE). Sebagian jaringan hepar juga diambil untuk dibuat sediaan yang akan diperiksa bagian ultra strukturnya dengan mikroskop elektron.

Penilaian kerusakan struktur hepatosit dilakukan dengan memeriksa sediaan histopatologik jaringan jaringan hepar dari seluruh sampel dari masing-masing kelompok eksperimen dan kelompok kontrol dibawah mikroskop cahaya dengan perbesaran 400x dan 1000x. Pemeriksaan difokuskan pada daerah antara vena sentralis dan segitiga Kiernan, yang terdiri atas zona sentrilobulear, zona midzonal, dan zona perifer. Daerah antara vena sentralis dan segitiga Kiernan terdiri atas 15 deretan hepatosit. Zona sentrilobular ialah deretan hepatosit ke-1 sampai ke5 mulai dari daerah disekeliling vena sentralis, zona midzonal ialah deretan hepatosit ke- 6 sampai ke-10, zona perifer ialah deretan hepatosit ke-11 sampai ke-15 menuju ke segitiga Kiernan.

Sel-sel hepatosit yang mengalami kerusakan struktur dihitung sesuai dengan derajat kerusakannya, yaitu: kerusakan tingkat I (degenerasi keruh), kerusakan tingkat II (degenerasi hidropik), kerusakan tingkat III (degenerasi lemak), kerusakan tingkat IV (nekrosis). Penghitungan hepatosit yang mengalami kerusakan struktur dilakukan dengan bantuan mikrometer berkisi yang dipasang diatas lensa okuler mikroskop cahaya. Penghitungan dilakukan pada 5 medan pandang mikroskop untuk tiap sediaan. 
Pada tiap medan pandang mikroskop diakukan penghitungan terhadap jumlah hepatosit yang mengalami kerusakan struktur pada tingkat I, tingkat II, tingkat III, dan tingkat IV. Pengamatan kerusakan ultra struktur hepatosit dilakukan dengan mikroskop elektron jenis Transmission Electron Microscope (TEM).

Pembuatan sediaan untuk pemeriksaan dengan mikroskop elektron dilakukan dengan mengiris potongan hepar mencit dengan ukuran $1 \times 1 \times 1 \mathrm{~cm}^{3}$, kemudian potongan hepar diproses sesuai standar pembuatan sediaan dengan pemeriksaan dengan mikroskop elektron. Setiap sediaan diperiksa kerusakan ultra struktur hepatosit khususnya pada membran nukleus, mitochondria, dan endoplasmic reticulum. Selanjutnya dilakukan pengamatan kerusakan masing-masing hepatosit pada tingkat sub seluler, khususnya pada ketiga organela tersebut akibat paparan patulin dalam 3 macam dosis. Sediaan kontrol juga diperiksa dengan cara yang sama. Analisis data dilakukan dengan ANOVA ganda, bila ada pengaruh yang sangat signifikan maka dilanjutkan dengan uji BNJ $1 \%$.

\section{HASIL}

Hasil penelitian pengaruh paparan patulin dengan beberapa macam dosis terhadap kerusakan struktur hepatosit mencit pada 3 zone lobulus hapar ditunjukkan pada Tabel 1. Berdasarkan data hasil penelitian diatas, dapat diketahui bahwa F hit dosis $(102113,910)>\mathrm{F}$ tab $1 \%$ $(0,000)$ yang menunjukkan bahwa ada pengaruh yang sangat signifikan pemberian dosis paparan patulin terhadap kerusakan struktur hepatosit mencit. $\mathrm{F}$ hit zona $(2251,688)>$ F tab $1 \%(0,000)$ yang menjukkan ada pengaruh yang sangat signifikan pada masing-masing zone yang mengalami kerusakan struktur hepatosit mencit. F hit dosis-zona $(442,059)>F$ tab $1 \%(0,000)$ yang menunjukkan bahwa ada pengaruh yang sangat signifikan pada interaksi antara dosis dengan zona lobulus hepar terhadap kerusakan struktur hepatosit mencit.

Tabel 1. Ringkasan ANOVA pengaruh paparan patulin terhadap kerusakan struktur hepatosit mencit

\begin{tabular}{lrrrrr}
\hline \multicolumn{1}{c}{ SK } & db & \multicolumn{1}{c}{ JK } & \multicolumn{1}{c}{ KT } & F hit & F tab 1\% \\
\hline Ulangan & 5 & 5886,403 & 1177,281 & 3,347 & 0,010 \\
Dosis & 3 & 10776471,6 & 3592157,199 & 102113,910 & 0,000 \\
Zona & 2 & 1583804,361 & 791902,181 & 2251,688 & 0,000 \\
Dosis-Zona & 6 & 932812,861 & 155468,810 & 442,059 & 0,000 \\
Galat & 55 & 19343,097 & 361,693 & & \\
Total & 71 & 13318318,3 & & & \\
\hline
\end{tabular}

Keterangan: SK=Sumber Keragaman, $d b=$ derajat bebas, $\mathrm{KT}=$ Kuadrat Tengah, JK=Jumlah Kuadrat

Untuk mengetahui perbedaan pengaruh macam dosis paparan patulin terhadap kerusakan struktur hepatosit pada ketiga zone lobulus hepar, maka dilakukan uji lanjut BNJ 1\% (Tabel 2). Hasil uji BNJ 1\% membuktikan bahwa dosis ke-III $(2,5 \mathrm{mg} / \mathrm{kg}$ BB) memberikan pengaruh tertinggi terhadap tingkat kerusakan struktur hepatosit mencit yang ditunjukkan dengan rerata kerusakan tertinggi. Semakin tinggi dosis paparan patulin yang diberikan, maka semakin tinggi tingkat kerusakan struktur hepatosit. Perbedaan dosis patulin memberikan perbedaan bermakna rerata kerusakan struktur hepatosit yang ditunjukkan dengan notasi yang berbeda.

Tabel 2. Uji BNJ 1\% pengaruh dosis paparan patulin terhadap kerusakan struktur hepatosit

\begin{tabular}{lcc}
\hline \multicolumn{1}{c}{ Dosis } & Rerata Kerusakan Struktur Hepatosit & Notasi* $^{*}$ \\
\hline Kontrol & 0 & a \\
$1 \mathrm{mg} / \mathrm{kg} \mathrm{BB}$ & 222 & $\mathrm{~b}$ \\
$1,75 \mathrm{mg} / \mathrm{kg} \mathrm{BB}$ & 665 & $\mathrm{C}$ \\
$2,5 \mathrm{mg} / \mathrm{kg} \mathrm{BB}$ & 997 & $\mathrm{~d}$ \\
\hline
\end{tabular}

Keterangan: "notasi berbeda menunjukkan perbedaan signifikan

Untuk mengetahui perbedaan pengaruh paparan patulin terhadap kerusakan struktur hepatosit pada ketiga zona lobulus hepar maka dilakukan uji BNJ 1\% (Tabel 3). Hasil uji BNJ 1\% pengaruh paparan patulin terhadap kerusakan struktur hepatosit pada ketiga zona lobulus hepar menunjukkan bahwa zona perifer merupakan zone lobulus hepar yang mengalami kerusakan struktur hepatosit tertinggi. Semakin ke arah perifer maka kerusakan struktur hepatosit yang mendapat papran patulin semakin meningkat.

Tabel 3. Uji BNJ 1\% pengaruh paparan patulin pada ketiga zone lobulus hepar

\begin{tabular}{lcc}
\hline Zone Lobulus Hepar & Rerata Kerusakan Struktur Hepatosit & Notasi \\
\hline Centrilobular & 292,042 & $\mathrm{a}$ \\
Midzonal & 466,750 & $\mathrm{~b}$ \\
Perifer & 655,250 & $\mathrm{c}$ \\
\hline
\end{tabular}

Keterangan: * notasi berbeda menunjukkan perbedaan signifikan

Foto mikroskopis hepatosit normal dan hepatosit yang mengalami kerusakan akibat paparan patulin pada dosis I, dosis II, dan dosis III dapat dilihat pada Gambar 3.
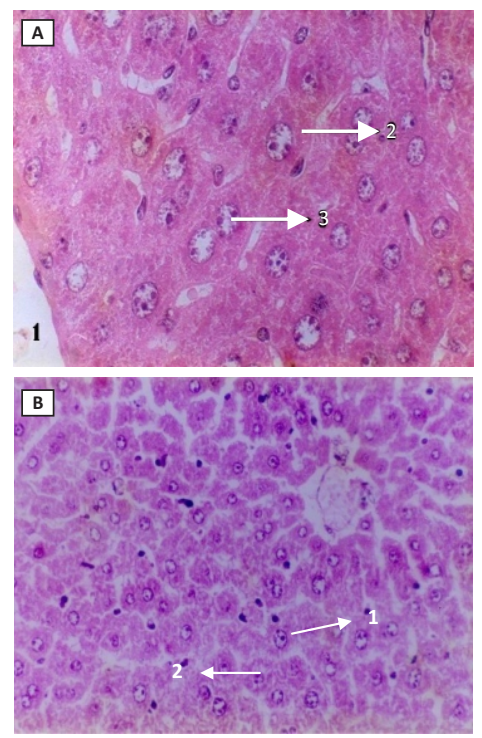

Gambar 3. Foto mikroskopis hepatosit normal dan hepatosit yang mengalami kerusakan akibat paparan patulin pada dosis I, dosis II, dan dosis III 

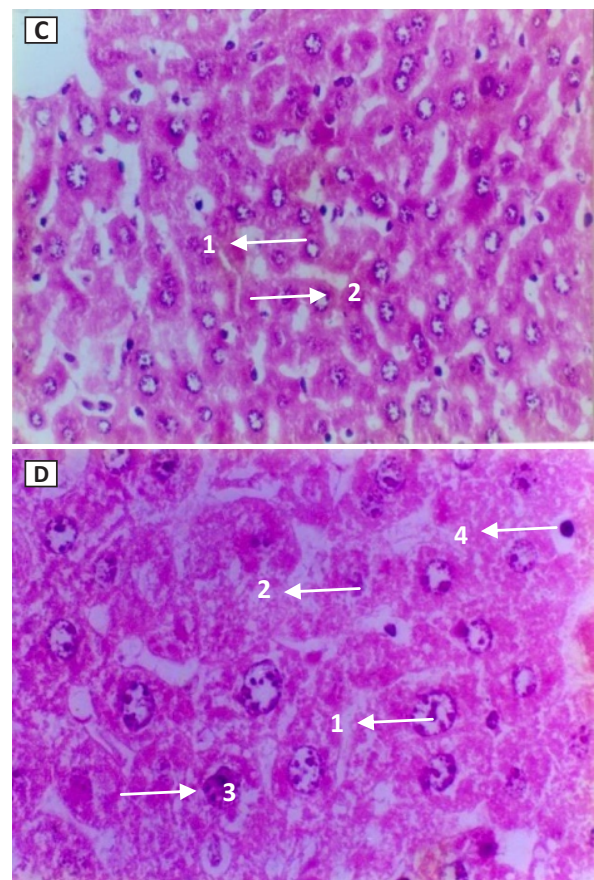

Keterangan:

A. Hepatosit normal. Panah: 1. Vena sentralis, 2. Hepatosit, 3. Nukleus

B. Hepatosit paparan patulin dosis I. Panah: 1. Hepatosit yang mengalami degenerasi keruh, 2. Hepatosit yang mengalami degenerasi hidropik

C. Hepatosit paparan patulin dosis II. Panah:1. Hepatosit yang mengalami degerasi keruh, 2. Hepatosit yang mengalami degenerasi hidropik

D. Hepatosit paparan patulin dosis III. Panah: 1. Hepatosit yang mengalami karioreksis, 2. Hepatosit yang mengalami kariolisis, 3. Hepatosit yang mengalami nekrosis, 4. Hepatosit yang mengalami degenerasi lemak

Gambar 3. Foto mikroskopis hepatosit normal dan hepatosit yang mengalami kerusakan akibat paparan patulin pada dosis I, dosis II, dan dosis III (Lanjutan)

Hasil pemeriksaan kerusakan ultra struktur pada hepatosit menggunakan Transmission Electron Microscope (TEM) menunjukkan bahwa kerusakan struktur hepatosit meningkat seiring dengan peningkatan dosis paparan patulin. Foto-foto electron micrograph hepatosit normal dan hepatosit yang mengalami kerusakan struktur akibat papran patulin dosis I, dosis II, dan dosis III dapat dilihat pada Gambar 4. Paparan patulin pada dosis I (1 mg/kg BB) menyebabkan mitochondria mulai membengkak, sedangkan membran nukleus dan endoplasmic reticulum masih dalam keadaan normal (Gambar 4b).

Paparan patulin dosis II $(1,75 \mathrm{mg} / \mathrm{kg}$ BB) menunjukkan efek kerusakan ultra struktur pada hepatosit yang makin meningkat. Mitochondria makin membengkak dan krista mitochondria nampak kabur, membran nukleus mulai rusak, sedangkan endoplasmic retikulum masih normal (Gambar 4c). Adapun paparan patulin dosis III $(2,5 \mathrm{mg} / \mathrm{kg}$ BB) menunjukkan efek kerusakan ultra struktur pada hepatosit yang tertinggi. Mitochondria sangat membengkak dan pecah, endoplasmic reticulum rusak dan terputus-putus, membran nukleus robek pada beberapa tempat, sitoplasma nampak berongga-rongga yang kemungkinan berasal dari organela-organela yang telah pecah dan lisis (Gambar 4d).
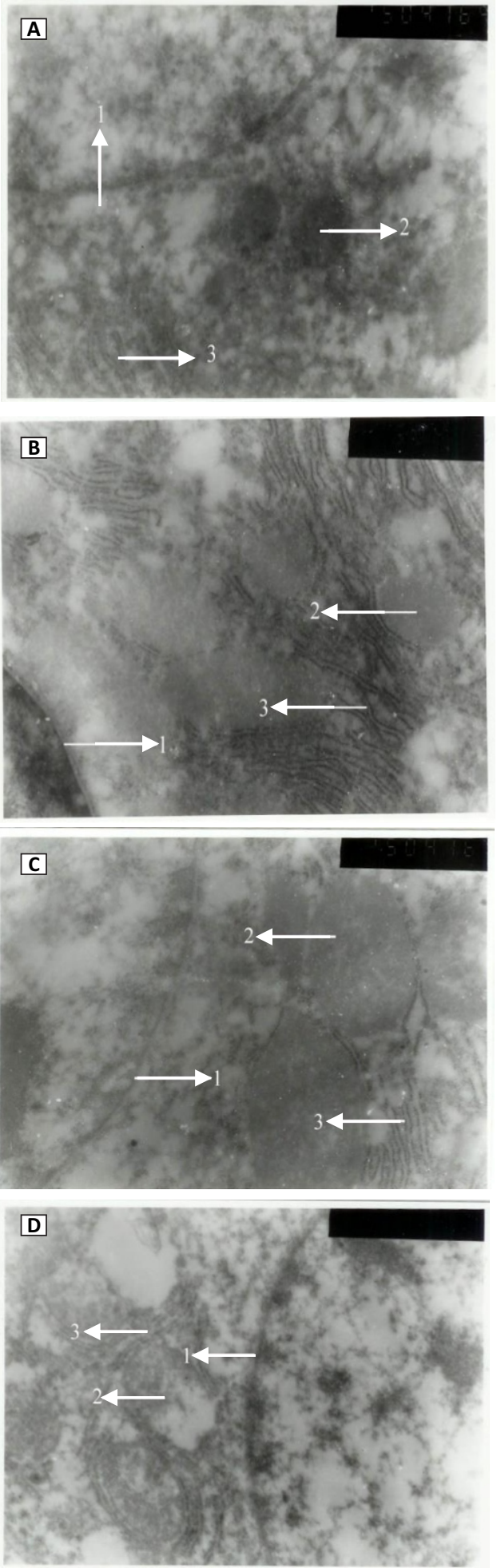

Keterangan:

A. Hepatosit normal. Notasi: 1. Membran nucleus, 2. Mitochondria, 3. Endoplasmic reticulum

B. Hepatosit pada paparan patulin dosis I. Notasi: 1. Membran nukleus normal, 2. Mitochondria mulai membengkak, 3. Endoplasmic reticulum normal

C. Hepatosit pada paparan patulin dosis II. Notasi: 1. Membran nukleus mulai rusak, 2. Mitochondria membengkak, 3. Endoplasmic reticulum normal

D. Hepatosit pada paparan patulin dosis III. Notasi: 1. Membran nukleus rusak, 2. Mitochondria rusak dan sebagian pecah, 3. Endoplasmic reticulum rusak dan terputus-putus

Gambar 4. Electron micrograph hepatosit normal dan pada paparan patulin dosis I, II dan III 


\section{DISKUSI}

Hasil penelitian ini membuktikan bahwa perlakuan pemberian patulin per oral pada mencit dapat menyebabkan kerusakan struktur maupun ultra struktur pada hepatosit. Kerusakan struktur hepatosit ditandai dengan adanya perubahan degeneratif yang terdiri dari: degenerasi keruh, degenerasi hidropik, degenerasi lemak, dan nekrosis. Gambar 4b menunjukkan bahwa paparan patulin dosis I ( $1 \mathrm{mg} / \mathrm{kg} \mathrm{BB}$ ) telah menyebabkan hepatosit mengalami degenerasi keruh dan degenerasi hidropik. Degenerasi keruh merupakan tingkat kerusakan struktur ke-I, yang ditandai dengan ciri-ciri antara lain: hepatosit membengkak, sitoplasma bergranula dan nampak tidak homogen, hal ini terjadi karena terjadi pemasukan air ke dalam hepatosit, sehingga sel membengkak. Organelaorganela sel juga turut menyerap air dan membengkak. Pada pengamatan mikroskopis nampak bergranula, sehingga nampak keruh (9). Bila kerusakan hepatosit berlanjut, maka terjadi degenerasi hidropik, yang merupakan tingkat kerusakan struktur ke-Il yang ditandai dengan terjadinya vakuolisasi akibat pemasukan air yang makin meningkat ke dalam sel. Hasil pemeriksaan dengan mikroskop elektron menunjukkan bahwa paparan patulin dosis I mengakibatkan mitokondria mulai membengkak akibat pemasukan air ke dalam organela tersebut.

Paparan patulin dosis II dan dosis III menyebabkan peningkatan kerusakan struktur hepatosit. Hasil menunjukkan bahwa paparan patulin dosis III $(2,5 \mathrm{mg} / \mathrm{kg}$ BB) menyebabkan hepatosit mengalami degenerasi lemak, yang merupakan tingkat kerusakan struktur ke-III serta nekrosis yang merupakan tingkat kerusakan struktur ke-IV. Nukleus hepatosit yang mengalami nekrosis telah rusak dan membran sel nampak kabur karena pecah. Hasil pengamatan dengan mikroskop elektron menunjukkan bahwa paparan patulin dosis II $(1,75 \mathrm{mg} / \mathrm{kg}$ BB) mengakibatkan membran nukleus mulai rusak dan mitokondria mulai membengkak. Pada pengamatan nampak bahwa paparan patulin dosis III $(2,5 \mathrm{mg} / \mathrm{kg}$ BB) menyebabkan membran nukleus rusak, mitokondria rusak dan sebagian pecah, serta endoplasmic reticulum mengalami kerusakan dan nampak terputus-putus.

Menurut Makfoeld, patulin bersifat hepatotoksik terhadap tikus. Meskipun demikian belum ada hasil penelitian yang menjelaskan tentang kerusakan struktur hepatosit pada ketiga zona lobulus hepar akibat paparan patulin. Betina mengemukakan bahwa paparan patulin per oral pada tikus menyebabkan oedema dengan pendarahan kerusakan pembuluh kapiler dalam ginjal, hepar, dan limpa. Hasil penelitian yang dilakukan oleh penulis telah memperkuat bukti bahwa paparan patulin dalam beberapa macam dosis dapat menyebabkan kerusakan struktur hepatosit mencit pada zona centrilobuler, zona midzonal, dan zona perifer. Selain itu terbukti pula bahwa paparan patulin menyebabkan kerusakan ultra struktur, khususnya pada mitokondria, endoplasmic reticulum, dan membran nukleus.

Apabila patulin masuk bersama-sama makanan yang telah terkontaminasi oleh mikotoksin tersebut ke dalam saluran pencernaan makanan, maka patulin akan masuk bersama-sama darah ke dalam hepar melalui vena porta hepatica. Vena membentuk cabang-cabang, yaitu vena interlobularis menuju ke lobus-lobus hepar. Cabangcabang tersebut membentuk cabang-cabang lagi, yaitu vena interlobularis, yang terdapat di daerah segitiga Kiernan. Selanjutnya darah yang mengandung patulin tersebut didistribusikan ke dalam sinusoid-sinusoid yang berbatasan dengan hepatosit-hepatosit, kemudian darah akan masuk ke dalam hepatosit-hepatosit. Zona perifer merupakan zona lobulus yang terletak paling dekat dengan vena interlobularis, bila dibandingkan dengan zone midzonal dan zona centrilobular. Hepatosit-hepatosit yang terdapat pada zona perifer, yang terletak disekitar daerah segitiga Kiernan, menerima pertama kali darah beserta zat-zat yang terkandung didalamnya yang masuk ke dalam hepar (10). Oleh karena itu hepatosit-hepatosit yang terletak pada zona perifer akan terpapar patulin lebih dahulu, kemudian di ikuti dengan hepatosit-hepatosit yang terletak pada zona midzonal dan pada zona centrilobular. Hasil penelitian ini juga membuktikan bahwa kerusakan struktur hepatosit yang tertinggi akibat paparan patulin terjadi pada zona perifer.

Paparan patulin ke dalam hepatosit dapat menyebabkan terbentuknya radikal bebas, maka terjadi peroksidasi lemak pada fosfolipid membran sel, sehingga mengakibatkan hilangnya integritas struktural dari membran hepatosit (11). Hal ini dapat menyebabkan semipermeabilitas membran sel menurun, sehingga mengakibatkan keluar masuknya senyawa-senyawa ke dalam sel tidak terkendali. Hal ini menyebabkan senyawasenyawa nutrisi dapat keluar dari dalam sel, sebaliknya senyawa-senyawa yang ada di luar sel dapat masuk ke dalam sel dengan lebih leluasa.

Patulin juga dapat menghambat aktivitas enzim $\mathrm{Mg}^{2+}$ ATP ase pada kultur hepatosit, maka hal ini mengakibatkan peningkatan kalsium intraseluler $(11,12)$. Selanjutnya peningkatan calcium intraseluler dapat mengaktifkan beberapa macam enzim, yaitu: phospholipase, protease, endonuklease, dan ATPase (9). Aktivitas enzim phospholipase dan protease mengakibatkan kerusakan pada membran plasma dan sistem membran pada organela-organela, terutama mitochondria dan endoplasmic reticulum. Aktivitas enzim ATPase dapat menyebabkan penurunan ATP, sehingga mengakibatkan terjadinya jejas seluler pada hepatosit. Penurunan ATP dapat menghambat sistem pompa Natrium dan Kalium ke dalam sel, sehingga mengakibatkan ion $\mathrm{Na}$ banyak tertimbun dalam sitoplasma. Hal ini menyebabkan peningkatan nilai osmosis dalam sitoplasma, sehingga terjadi pemasukan air dari ruang antar sel ke dalam hepatosit, selanjutnya terjadi penggembungan sel dan organela-organela sel termasuk mitochondria, sehingga mengakibatkan pecahnya hepatosit yang di sebut nekrosis.

Apabila terjadi hambatan aktivitas enzim-enzim respirasi akibat paparan patulin, maka dapat menyebabkan kerusakan struktur hepatosit, selain itu juga dapat menyebabkan kerusakan pada mitochondria. Enzimenzim respirasi yang keluar dari dalam sitoplasma dan mitochondria dapat mengakibatkan hambatan pada respirasi seluler, sehingga terjadi kematian hepatosit.

Dapat disimpulkan bahwa pemberian patulin pada berbagai dosis dapat menyebabkan kerusakan struktur dan ultra struktur heaptosit pada mencit. Semakin tinggi dosis semakin besar kerusakan yang ditimbulkan dengan kerusakan tertinggi pada dosis $2,5 \mathrm{mg} / \mathrm{kgBB}$. Kerusakan hepatosit terjadi pada semua zona lobulus hepar dengan kerusakan tertinggi ditemukan pada zona perifer. 


\section{DAFTAR PUSTAKA}

1. Hastuti US. Mikoflora pada Biji Lada Utuh dan biji Lada Rusak di Kodya Malang. Makalah disajikan pada PIT dan Seminar Nasional Mikrobiologi PERMI. Malang, 12-13 November 1996.

2. Pitt JI and AD Hocking. Fungi and Food Spoilage. North Ryde, Sydney: Springer; 2009.

3. Jimenes $M$, Mateo $R$, Querol $A$, Huerta $T$, and Hernandez E. Mycotoxins and Mycotoxigenic Moulds in Nuts and Sunflower Seeds for Human Consumption. Mycopathologia. 1991; 115(2): 121-127.

4. Pratiwi ST. Mikrobiologi Farmasi. Jakarta: Penerbit Erlangga; 2008; hal. 176-185.

5. Makfoeld D. Mikotoksin Pangan. Yogyakarta: Penerbit Kanisius; 1993.

6. Tortora J, Funke BR, and Case CL. Microbiology an Introduction. San Francisco. Pearson Education, Inc; 2004.
7. Betina V. Mycotoxins-Chemichal, Biologycal, and Enviromental Aspect. Canada: Elsevier Science; 1989; pp. 174-265.

8. Kogika MM, Hagiwara MK, and Mirandola RM. Experimental Citrinin Nephrotoxicosis in Dogs: Renal Function Evaluation. Veterinary \& Human Toxicology. 1993; 35(2): 136-140.

9. Kumar V, Abbas AK, Aster JC, and Fausto N. Robins \& Cotran Pathologic Basis of Disease. 8th edition. Philadelphia: WB Saunders Company; 2010.

10. Klaassen CD. Casarett and Doull's Toxicology: The Basic Science of Poisons. New York: McGraw-Hill Companies, Inc; 2008.

11. Barhoumi R and Burghardt RC. Kinetic Analysis of the Chronology of Patulin and Gossypol-Induced Cytotoxicity In Vitro. Fundamental and Applied Toxicology. 1996; 30(2): 290-297.

12. Hayes AW. Mycotoxin Teratogenicity and Mutagenicity. Florida: CRC Press, Inc; 1981. 